\title{
The effect of the protein level in diets of Polish Lowland lambs on growth and fattening
}

\author{
J.J. Pająk, Teresa Żebrowska and Magdalena Słowak
}

\author{
The Kiclanouski Institute of Animal Physiology and Nutrition, Polish Academy of Sciences \\ 05-110 Jabtonna, Poland
}

(Received 31 October 1994; accepted 19 December 1994)

\begin{abstract}
Starting from the eleventh day of life, three groups of 48 suck ling Polish Lowland lambs each were fed to appetite with meadow hay and a concentrate containing $16.7,14.7$ or $12.3 \%$ crude protein (CP) in dry matter (DM). Consumption of the concentrate decreased as the protein content decreased, while the proportion of hay DM in total consumed DM increased from 41 to about 43 and $46 \%$, respectively. No statistically significant differences were found in body weight gains (male, 173, 134 and $146 \mathrm{~g} /$ day; female, 144,134 and $136 \mathrm{~g} /$ day, respectively) or body weight of suckling lambs from day 28 of life to weaning. Utilization of DM and metabolizable energy (ME) per $\mathrm{kg}$ gain was similar (2.16,2.17 and $2.08 \mathrm{~kg} \mathrm{DM}$ and about $25 \mathrm{MJ} \mathrm{ME}$ ), whereas protein utilization improved as its content in the diet decreased $(322,297$ and $258 \mathrm{~g}$ crude protein $/ \mathrm{kg}$ gain, respectively).

No significant differences among the gains of 92 young rams (from 221 to $232 \mathrm{~g} /$ day) were observed in four groups of 23 rams each fed diets differing in their protein level ( $16 \mathrm{vs} 14 \% \mathrm{CP}$ in DM) and source (soyabean oilmeal (SBM) or rapeseed oilmeal (RSM), from a double - low variety). The utilization of fced DM was somewhat better in group that received SBM $\left(\mathrm{S}^{\mathrm{H}}\right)$ than in the group receiving $\mathrm{RSM}\left(\mathrm{R}^{\mathrm{H}}\right)$ in the high protein ration ( $4.43 \mathrm{vs} 4.67 \mathrm{~kg} \mathrm{DM} / \mathrm{kg}$ gain, respectively), whilc when the protein content was lowered, feed utilization did not differ between groups (4.54 vs $4.67 \mathrm{~kg}$ $\mathrm{DM} / \mathrm{kg}$ gain, respectively). Protein utilization did not differ between groups receiving the same amount of protein in their diets, but was worse $(P \leqslant 0.05)$ in group $R^{H}(741$ vs 639 and $634 \mathrm{~g} / \mathrm{kg}$ ) than in both groups fed a diet with a lower protein content $\left(S^{\mathrm{L}}\right.$ and $\left.\mathrm{R}^{\mathrm{L}}\right)$.

The lambs fed the rations with the highest protein level $(16.7 \%$ in $\mathrm{DM})$ grew somewhat more slowly during fattening ( 217 vs 232 or $227 \mathrm{~g} / \mathrm{day}$ ) and consumed significantly more feed $(\mathrm{P} \leqslant 0.05)$ than those given the feeds containing 14.7 or $12.3 \% \mathrm{CP}$ in DM $\left(4.83^{\mathrm{a}}\right.$ vs $4.30^{\mathrm{b}}$ or $4.49^{\mathrm{b}} \mathrm{DM} / \mathrm{kg}$ gain $)$.
\end{abstract}

KEY WORDS: Polish Lowland lambs, protein level, suckling lambs, fattening, feeding standards

\section{INTRODUCTION}

There are no reports in the relevant literature on the effect of nutrition of Polish Lowland suckling lambs on their later growth and performance during 
fattening. Only a few papers deal with the feeding of suckling lambs Polish Merino breeds (Potkański et al., 1991; Urbaniak and Potkański, 199la). No other studies have been undertaken to assess the effect of limiting the protein content in rations for suckling lambs on their later fattening performance.

The results of our previous studies (Żebrowska et al., 1992; Pająk et al., 1993) have shown that Polish Merino and Polish Lowland lambs fed isocaloric rations with a lower crude protein level (14-15\%) during fattening showed a similar weight gain as those fed the 16-17\% recommended in Polish standards. These results are corroborated by the studies of Shindarska (1987), Sinclair et al. (1991), Urbaniak (1986) and partially by that of Purroy et al. (1993). It thus seems reasonable that suckling lambs, whose major dietary component is their mother's milk - especially in the initial period of life, when their growth rate shows a positive correlation with their mother's milk output (Snowder and Glimp, 1991) - could receive less than the $17 \%$ crude protein in the supplementary feed given to them according to Polish standards (Nutrient Requirements of Cattle and Sheep, Traditional System (1993).

The purpose of this study was to assess the effect of lowering the crude protein content in rations fed to suckling lambs and fattening male lambs of the Polish Lowland breed, as well as determining the effect of feeding during initial growth on fattening performance.

\section{MATERIAL AND METHODS}

\section{Suckling period}

The experiment was conducted on three groups of 48 twins each (two male lambs or one mixed pair) of nearly the same age. Three days after lambing the mothers and their lambs were transferred to a common pen (housing 24 mothers) with separated area for supplementary feeding of the lambs to which the mothers did not have access. The mothers in all groups were fed similarly received hay, grass silage and concentrate. Starting from the eleventh day of life the lambs were offered meadow hay and feed concentrates with various protein concentrations (Table 2): group $\mathrm{H}, 16.7 ; \mathrm{M}, 14.7 ; \mathrm{L}, 12.3 \%$ crude protein $(\mathrm{CP})$ in dry matter (DM). The lambs had free access to the feed and water and to blocks of salt containing microelements. The concentrate and hay was offered twice daily, the refusals are collected and weighed in the morning before new feed was given. The lambs were weighed at 2 and 28 days of age and on two successive days before weaning. Feed consumption and utilization between day 28 of life to weaning at about 92 days of age were determined, as were daily weight gains. 
TABLE 1

Experimental design

\begin{tabular}{|c|c|c|c|c|}
\hline Suckling period & \multicolumn{4}{|c|}{ Subgroups at fattening period } \\
\hline Protcin source & \multicolumn{2}{|c|}{ Soyabean oilmeal } & \multicolumn{2}{|c|}{ Rapeseed oilmeal } \\
\hline Protein in DM of ration & $16 \%$ & $14 \%$ & $16 \%$ & $14 \%$ \\
\hline $\mathrm{H}$ & ${ }_{11} \mathrm{~S}^{\mathrm{H}}$ & ${ }_{H} S^{L}$ & ${ }_{\mathrm{H}} \mathbf{R}^{\mathrm{H}}$ & ${ }_{H} \mathbf{R}^{\mathbf{L}}$ \\
\hline $\mathrm{M}$ & ${ }_{M} \mathrm{~S}^{\mathrm{H}}$ & ${ }_{M} S^{L}$ & ${ }_{M} R^{11}$ & ${ }_{M} R^{L}$ \\
\hline $\mathrm{L}$ & ${ }_{L} S^{\prime \prime}$ & ${ }_{L} S^{L}$ & ${ }_{\mathbf{L}} \mathbf{R}^{\mathrm{H}}$ & ${ }_{L} \mathrm{R}^{\prime}$ \\
\hline Group at fattening period & $S^{H}$ & $\mathrm{~S}^{\mathrm{L}}$ & $R^{H}$ & $\mathrm{R}^{\mathrm{L}}$ \\
\hline
\end{tabular}

TABLE 2

Composition and feeding value of concentrate for suckling lambs

\begin{tabular}{lccc}
\hline Component & H & G r u p \\
& M & L \\
\hline Rolled barley, \% & 65.6 & 80.9 & 98.0 \\
Wheat bran, \% & 16.5 & 8.7 & - \\
Soyabean oilmeal, \% & 15.9 & 8.4 & - \\
Mineral-vitamin supplement*, \% & 2.0 & 2.0 & 2.0 \\
In DM of concentrate & & & \\
Crude protein, \% & 16.7 & 14.7 & 12.3 \\
$\quad$ degradable & 13.6 & 12.3 & 10.6 \\
undegradable & 3.1 & 2.4 & 1.7 \\
PDIN, g & 115 & 96 & 75 \\
PDIE, g & 107 & 97 & 87 \\
UFV & 1.06 & 1.09 & 1.11 \\
Metabolizable energy, MJ & 12.9 & 13.0 & 13.2 \\
q (ME/GE) & 0.67 & 0.68 & 0.69 \\
\hline
\end{tabular}

* calcium carbonate $-45 \%$, dicalcium phosphate $-25 \%$, mineral-vitamin supplement Polfamix $\mathrm{CJ}$ $-15 \%$, sodium chloride $-15 \%$

\section{Fattening period}

The experimental design is presented in Table 1. Thirty-two rams from groups $\mathrm{H}$ and $\mathrm{L}$ and 28 rams from group $\mathrm{M}$ were chosen after weaning and divided into 4 subgroups of 8 each $\left(S^{H}, S^{L}, R^{H}, R^{L}\right)$ from groups $\mathrm{H}$ and $\mathrm{L}$ and 7 rams each from group $\mathrm{M}$. The lambs were fed in groups, taking into account the DM requirement according to Polish standards (1993), and received rations with equivalent energy 
contents (about 12.5 MJ metabolizable energy, ME/ $\mathrm{kg} \mathrm{DM}$ ) containing 16 (groups $\mathrm{S}^{\mathrm{H}}$ and $\mathrm{R}^{\mathrm{H}}$ ) or $14 \% \mathrm{CP}$ (groups $\mathrm{S}^{\mathrm{L}}$ and $\mathrm{R}^{\mathrm{L}}$ ). The rams were offered meadow hay and feed concentrate (Table 6) in two daily portions: groups $\mathrm{S}^{\mathrm{H}}$ and $\mathrm{S}^{\mathrm{L}}$ were given soyabean oilmeal (SBM), while groups $\mathrm{R}^{\mathrm{H}}$ and $\mathrm{R}^{\mathrm{L}}$ received double - low rapeseed oilmeal (RSM). Unconsumed feed was collected and weighed once daily before new feed was offered. The lambs were fattened to a liveweight of $40 \mathrm{~kg}$. The lambs were weighed for two successive days before beginning fattening and every two weeks during fattening in order to adjust the feed ration to body weight. The animals were kept on wheat straw with free access to water and blocks of salt.

Feeds were analyzed by the conventional methods. Protein degradation in the rumen was assessed according to Mehrez and Ørskov (1977) on three wethers with an average weight of $70 \mathrm{~kg}$. Effective protein degradation in the rumen at $k=0.06$ was calculated according to Ørskov and McDonald (1979). The PDIN and PDIE contents were computed based on the determined rumen protein degradation and coefficients given by INRA (1993). Metabolizable energy was calculated using the MAFF equation (1975). The amount of ME available for growth was calculated assuming, as given by Theriez et al. (1982), that the maintenance requirement for lambs equals $418 \mathrm{~kJ}$ ME per $\mathrm{kg}$ metabolic body weight $\left(\mathrm{W}^{0.75}\right)$.

Feed consumption and utilization as well as the daily weight gain of the lambs were determined. Feed intake was compared with the requirements given in the Polish Nutrient Requirements of Cattle and Sheep, Traditional System (1993), and in the INRA system (1993).

The statistical analysis was carried out using the Statgraphics Plus ver 7. program for variance analysis.

\section{RESULTS}

\section{Suckling period}

In comparison with the control lambs in group $\mathrm{H}$ which were fed a diet with a composition close to that given in the Polish standards (Table 2), the lambs in group $\mathrm{M}$ received $12 \%$ less $\mathrm{CP}$ in $\mathrm{DM}$ of the feed concentrate, while those in group L, $26 \%$ less. The intake of feed decreased along with its protein content, while meadow hay accounted for an increasing proportion of DM consumed (Table 3). The DM in the consumed ration in groups $\mathrm{M}$ and $\mathrm{L}$ contained 8 and $17 \%$ less $\mathrm{CP}$, respectively, than in group $\mathrm{H}$. Taking into account the fact that the real value of the protein degraded in the small intestine (PDI) is determined by the lesser of the two values, PDIN or PDIE, it was found that in groups M and L, 
TABLE 3

Composition and feeding value of rations consumed by suckling lambs

\begin{tabular}{lccc}
\hline Component & \multicolumn{3}{c}{ G r o u p } \\
& H & M & L \\
\hline Concentrate, \% $\%$ & 59.0 & 57.3 & 54.3 \\
Meadow hay, $\%$ & 41.0 & 42.7 & 45.7 \\
Crude protein, \% & 14.9 & 13.7 & 12.4 \\
degradable & 10.9 & 10.1 & 9.2 \\
undegradable & 4.0 & 3.6 & 3.2 \\
PDIN, g & 100 & 88 & 79 \\
PDIE, g & 97 & 92 & 86 \\
UFV & 0.90 & 0.90 & 0.90 \\
Metabolizable energy, MJ & 11.8 & 11.8 & 11.9 \\
q (ME/GE) & 0.59 & 0.59 & 0.59 \\
\hline
\end{tabular}

PDIN was the limiting factor and its content in relation to PDIE, which limited the value of the protein in group $\mathrm{H}$, was lower by 9 and $19 \%$, respectively.

No significant differences were found among the groups in terms of weight gain and body weight during the particular periods of growth of the suckling lambs, this because of the high variability within groups (Table 4). A somewhat faster growth rate, especially after 28 days of age, was observed in the male lambs in group $\mathrm{H}$. The rams were more sensitive than the ewes to lowering the protein level in the concentrate, which was reflected in smaller gains: rams by 23 and $16 \%$ and ewes by 7 and $6 \%$ in groups $\mathrm{M}$ and $\mathrm{L}$ as compared with the lambs in group $\mathrm{H}$.

No differences in feed utilization were found among the lambs from 28 days of age to weaning. Utilization of DM and ME per $\mathrm{kg}$ gain was similar, while protein utilization improved when its level in the concentrate decreased (Table 5). The highest daily DM consumption was found in group $\mathrm{H}$, in the remaining groups it was about $15 \%$ lower when calculated per $\mathrm{kg}$ metabolic weight $\left(\mathrm{W}^{0.75}\right)$, regardless of the protein level. The lambs did not consume the expected amounts of DM and CP; daily DM intake was 10,24 and $22 \%$ lower, while that of CP 14,34 and even $39 \%$ lower in groups H, M, L, respectively. In all of the groups the lambs consumed sufficient amounts of $\mathrm{ME}$ with their ration to cover their maintenance requirements and $1.11,0.47$ and $0.43 \mathrm{MJ} \mathrm{ME}$ to cover their growth requirements in groups $H, M$ and $L$, respectively (Table 5 ).

\section{Fattening period}

The animals left only small amounts of concentrate, similar in all groups. This led to a small rise in the proportion of hay in the daily ration (Table 7) in respect 


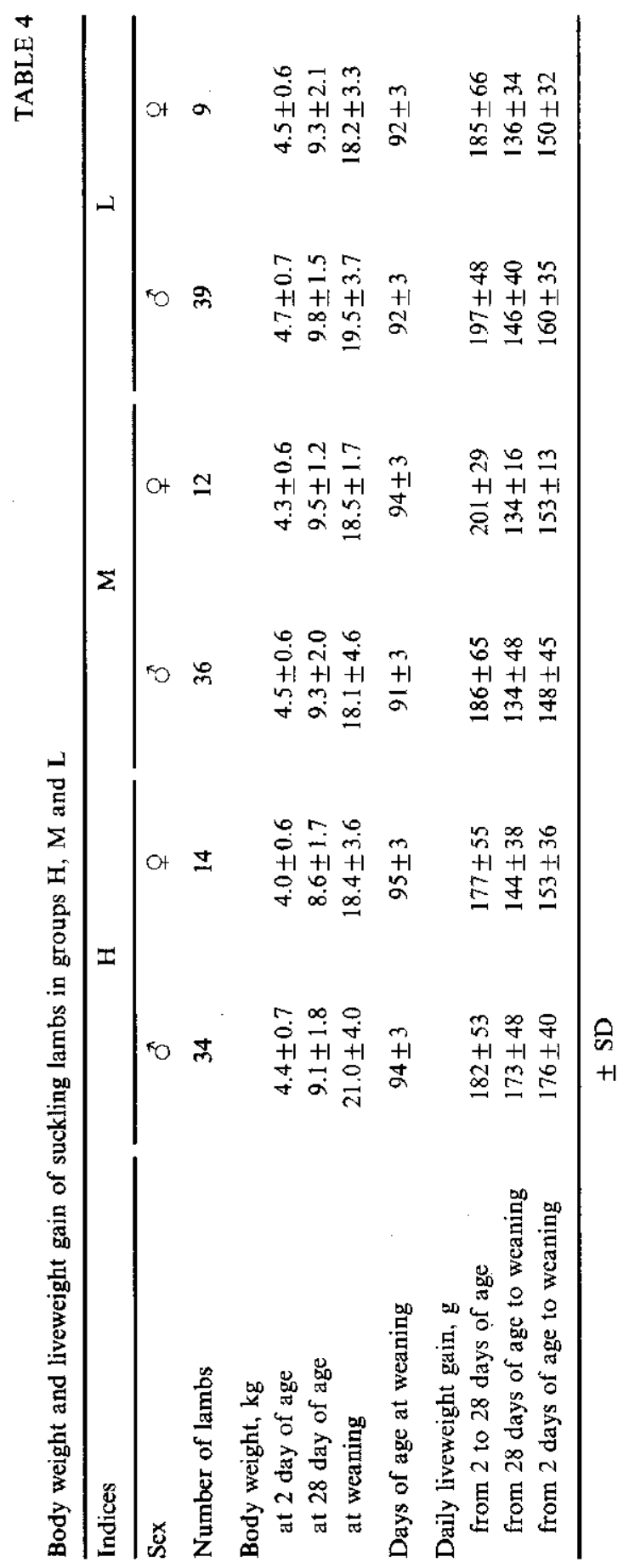


TABLE 5

Feed utilization in suckling period

(milk is not taken into account in this calculation)

\begin{tabular}{|c|c|c|c|}
\hline \multirow{2}{*}{ Indices } & \multicolumn{3}{|c|}{ Group } \\
\hline & $\mathrm{H}$ & M & $\mathbf{L}$ \\
\hline Number of lambs & 48 & 48 & 48 \\
\hline \multicolumn{4}{|l|}{ Feed utilization per $\mathrm{kg}$ of gain: } \\
\hline dry matter, $\mathrm{kg}$ & 2.16 & 2.17 & 2.08 \\
\hline crude protein, $\mathrm{g}$ & 323 & 298 & 257 \\
\hline metabolizable energy, MJ & 25.4 & 25.6 & 24.6 \\
\hline \multicolumn{4}{|l|}{ Intake $/$ day $/ \mathbf{W}^{0.75}$} \\
\hline dry matter, $\mathrm{g}$ & 47.7 & 40.6 & 40.3 \\
\hline crude protein, g & 7.1 & 5.6 & 5.0 \\
\hline metabolizable energy, $\mathrm{MJ}$ & 0.56 & 0.48 & 0.48 \\
\hline \multicolumn{4}{|c|}{ Intake as per cent of requirement* } \\
\hline dry matter & 90 & 76 & 78 \\
\hline crude protein & 86 & 66 & 61 \\
\hline \multicolumn{4}{|c|}{ Daily maintenance requirement** } \\
\hline metabolizable energy, $\mathrm{MJ}$ & 3.12 & 2.98 & 3.11 \\
\hline
\end{tabular}

* according to Polish standards (Instytut Zootechniki,1993)

** calculated: $418 \mathrm{~kJ} \times$ mean metabolic weight

TABLE 6

Composition of the ration for fattening lambs. $\%$

\begin{tabular}{|c|c|c|c|c|}
\hline \multirow[b]{2}{*}{ Ingredients } & \multicolumn{4}{|c|}{ Group } \\
\hline & $S^{H}$ & $\mathbf{S}^{1}$ & $\mathrm{R}^{\mathrm{H}}$ & $\mathrm{R}^{\mathrm{L}}$ \\
\hline Soyabean oilmeal & 10.8 & 5.4 & - & - \\
\hline Rapeseed oilmeal & - & - & 10.8 & 5.4 \\
\hline Rolled barley & 57.6 & 68.0 & 57.6 & 68.0 \\
\hline Wheat bran & 10.0 & 5.0 & 10.0 & 5.0 \\
\hline Mineral-vitamin supplement* & 1.6 & 1.6 & 1.6 & 1.6 \\
\hline Meadow hay & 20.0 & 20.0 & 20.0 & 20.0 \\
\hline
\end{tabular}

* as in table 2 
Composition and fecding value of dry matter consumed in fattening period

\begin{tabular}{|c|c|c|c|c|}
\hline \multirow{2}{*}{ Component } & \multicolumn{4}{|c|}{ G roup } \\
\hline & $S^{H}$ & $\mathrm{~S}^{\mathrm{T} .}$ & $\mathrm{R}^{\mathrm{H}}$ & $\mathrm{R}^{\mathrm{L}}$ \\
\hline Concentrate, $\%$ & 78.0 & 78.1 & 78.8 & 77.7 \\
\hline Meadow hay, \% & 22.0 & 21.9 & 21.2 & 22.3 \\
\hline Crude protein, \% & 15.9 & 14.1 & 15.9 & 14.1 \\
\hline degradable & 12.0 & 10.9 & 12.2 & 10.9 \\
\hline undegradable & 3.8 & 3.2 & 3.7 & 3.1 \\
\hline PDIN, g & 102 & 89 & 99 & 87 \\
\hline PDIE. $\mathrm{g}$ & 99 & 93 & 94 & 90 \\
\hline UFV & 0.98 & 1.00 & 0.97 & 0.99 \\
\hline Metabolizable energy, MJ & 12.3 & 12.5 & 12.3 & 12.4 \\
\hline $\mathrm{q}(\mathrm{ME} / \mathrm{GE})$ & 0.63 & 0.63 & 0.62 & 0.63 \\
\hline
\end{tabular}

to the methodological assumptions. The lambs from groups $\mathrm{S}^{\mathrm{L}}$ and $\mathrm{R}^{\mathrm{L}}$ consumed about $11 \%$ less $\mathrm{CP}$, including about $16 \%$ less protein undegraded in the rumen than the lambs in groups $S^{H}$ and $R^{H}$. In groups $S^{L}$ and $R^{L}$, the factor limiting PDI was PDIN, and its content in comparison with the limiting factor in groups $\mathrm{S}^{\mathrm{H}}$ and $R^{H}$, PDIE, was lower by 10 and $17 \%$ in groups $S^{H}$ and $R^{H}$, respectively.

Comparison of feed intake with Polish and INRA standards (Table 8) shows that both groups fed according to Polish standards ate about 12 (group $\mathrm{S}^{\perp}$ ) to about $17 \%$ (group $\mathrm{R}^{\mathrm{H}}$ ) less DM and about $11\left(\right.$ group $^{\mathrm{H}}$ ) to $15 \%$ (group $\mathrm{R}^{\mathrm{H}}$ ) less $\mathrm{CP}$ than recommended by the Polish standards (1993). The PDI requirement was exceeded only in group $\mathrm{S}^{\mathrm{H}}$ by $7 \%$ (PDIE), while the lambs fed rations with a decreased protein level $\left(\mathrm{S}^{\mathrm{L}}\right.$ and $\mathrm{R}^{\mathrm{L}}$ ) consumed about $10 \%$ less PDIN in relation to the requirements for protein digested in the intestine according to the INRA system (1993). The energy requirements of the lambs according to this system were also not covered.

No significant differences were found in the gains of the lambs in relation to protein level and source (Table 9). At both protein levels, the gains of lambs receiving RSM in their rations (groups $R^{H}$ and $R^{L}$ ) were only few grams less than of those lambs receiving SBM (groups $S^{H}$ and $S^{L}$ ). Utilization of feed DM was somewhat better $(\mathbf{P}>0.05)$ in group $\mathrm{S}^{\mathrm{H}}$ receiving SBM than in the RSM group (group $\mathrm{R}^{\mathrm{H}}$ ) in the high protein ration, while it did not differ when the protein level decreased. The utilization of $\mathrm{CP}$ within protein level groups did not differ significantly, but was worse in group $R^{\mathrm{H}}$ than in groups $\mathrm{S}^{\mathrm{L}}$ and $\mathrm{R}^{\mathrm{L}}$.

Comparison of consumption of ME available for growth and daily weight gains of fattened lambs shows that the decrease in daily gains in the lambs fed rations containing RSM corresponded with the decline in the amount of energy available for growth (Table 10). 
TABLE 8

The nutritive value of consumed rations in comparison with recommended allowances by Polish and INRA feeding standards

\begin{tabular}{|c|c|c|c|c|}
\hline \multirow{2}{*}{ Intake as per cent of requirement } & \multicolumn{4}{|c|}{ Group } \\
\hline & $\mathrm{S}^{\mathrm{H}}$ & $\mathrm{S}^{\mathrm{L}}$ & $\mathbf{R}^{H}$ & $\mathbf{R}^{\mathbf{l}}$ \\
\hline \multicolumn{5}{|l|}{ Polish feeding standards } \\
\hline dry matter & 88 & 84 & 83 & 84 \\
\hline crude protein & 89 & 75 & 85 & 76 \\
\hline \multicolumn{5}{|l|}{ INRA feeding standards* } \\
\hline PDIN** & 110 & 91 & 101 & 90 \\
\hline PDIE & 107 & 95 & 96 & 93 \\
\hline UFV & 97 & 93 & 89 & 92 \\
\hline
\end{tabular}

* male lambs, moderate growth potential, 250 giday

** as per cent of PDI requirement

TABLF 9

Body weight, liveweight gain and feed utilization of fattening lambs

\begin{tabular}{|c|c|c|c|c|}
\hline Indices & $\mathrm{S}^{\mathrm{H}}$ & $\mathrm{S}^{\mathrm{L}}$ & $\mathbf{R}^{\mathrm{H}}$ & $\mathbf{R}^{\mathrm{L}}$ \\
\hline Number of lambs & 23 & 23 & 23 & 23 \\
\hline \multicolumn{5}{|l|}{ Body weight, kg } \\
\hline initial & $20.0 \pm 3.5$ & $20.3 \pm 3.3$ & $20.5 \pm 3.2$ & $20.2 \pm 3.3$ \\
\hline final & $38.5 \pm 1.7$ & $38.6 \pm 2.3$ & $39.2 \pm 1.2$ & $39.0 \pm 1.5$ \\
\hline Daily liveweight gain, $\mathrm{g}$ & $232 \pm 51$ & $225 \pm 54$ & $221 \pm 42$ & $222 \pm 49$ \\
\hline \multicolumn{5}{|l|}{ Feed utilization: } \\
\hline dry matter, $\mathrm{kg} / \mathrm{kg}$ & $4.43 \pm 0.27$ & $4.54 \pm 0.35$ & $4.67 \pm 0.15$ & $4.51 \pm 0.39$ \\
\hline crude protein, $\mathrm{g} / \mathrm{kg}$ & $702 \pm 43^{a}$ & $639 \pm 50^{20}$ & $741 \pm 23^{\circ}$ & $634 \pm 55^{\mathrm{ab}}$ \\
\hline metabolizable energy, $\mathrm{MJ} / \mathrm{kg}$ & $54.6 \pm 3.3$ & $56.5 \pm 4.4$ & $57.5 \pm 1.9$ & $56.0 \pm 4.9$ \\
\hline
\end{tabular}

$a, b \quad P \leqslant 0.05$

TABLE 10

Intake of metabolizable energy (MEg) for growth, (MJ/day) and daily livewcight gain (dlg) of fattening lambs

\begin{tabular}{lcccc}
\hline Group & MFg & $\%$ & dlg & $\%$ \\
\hline Crude protein - 16\% & & & & \\
S & & & \\
SBM) & 6.75 & 100 & 232 & 100 \\
R $^{\mathrm{H}}$ (RSM) & 6.44 & 95.4 & 221 & 95.3 \\
Crude protein - 14\% & & & & \\
S $^{\mathrm{L}}$ (SBM) & 6.59 & 100 & 225 & 100 \\
R $^{\mathrm{L}}$ (RSM) & 6.51 & 98.8 & 222 & 98.7 \\
\hline
\end{tabular}


TABLE 11

Mean liveweight gain and feed utilization in fattening period of lambs given $\mathrm{H}, \mathrm{M}$ and $\mathrm{L}$ diets before weaning.

\begin{tabular}{lccc}
\hline Indices & $\mathrm{H}$ & $\mathrm{M}$ & $\mathrm{L}$ \\
\hline Number of lambs & 32 & 28 & 32 \\
Daily liveweight gain, g & $217 \pm 36$ & $232 \pm 55$ & $227 \pm 55$ \\
Fecd utilization/kg gain: & & & \\
$\quad$ dry matter, kg & $4.83 \pm 0.10^{\mathrm{a}}$ & $4.30 \pm 0.19^{\mathrm{b}}$ & $4.49 \pm 0.19^{\mathrm{b}}$ \\
$\quad$ crude protein, g & $723 \pm 37$ & $643 \pm 60$ & $671 \pm 63$ \\
metabolizablc encrgy. MJ & $59.9 \pm 1.5$ & $53.2 \pm 2.3$ & $55.5 \pm 2.2$ \\
\hline
\end{tabular}

$a, b \quad P \leqslant 0.05$

The suckling lambs fed the concentrate with the highest protein content ( $16.7 \%$ in DM, group $\mathrm{H}$ ) grew somewhat more slowly during fattening and used significantly more feed $\mathrm{DM} / \mathrm{kg}$ weight gain $(\mathrm{P} \leqslant 0.05)$ than the remaining animals receiving feeds containing 14.7 (group $\mathrm{M}$ ) or $12.3 \%$ (group L) $\mathrm{CP}$ in $\mathrm{DM}$ (Table 11).

\section{DISCUSSION}

\section{Suckling period}

The Polish Lowland sheep is a breed that is not fully stabilized genetically. A high degree of individual variability was therefore observed in respect to most of the analyzed traits. Thus, the differences in the average values of the studied traits were not proven to be statistically significant in most cases.

A reduction in feed intake in response to lowering the protein level of the diet (Table 3) is a known reaction (e.g. Ensminger et al., 1990). Although a reduction in the $\mathrm{CP}$ level in the concentrate by 12 and $26 \%$, respectively in groups $\mathrm{M}$ and $\mathrm{L}$ in comparison with group $\mathrm{H}$ led to a decrease in the amount of protein digestible in the intestine (PDI) in the consumed ration by about 9 and $22 \%$, the reaction of the suckling lambs was similar - a reduction in intake of $D M / \mathrm{kg}^{0.75}$ by 14.8 and $15.5 \%$ in groups $\mathrm{M}$ and $\mathrm{L}$, respectively (Table 5 ). We were not able to find any explanation for this reaction in the literature. Villette and Theriez (1981) report that during suckling period, feed intake per $\mathrm{kg}$ metabolic weight was unrelated to the birth weight of male lambs, while their mean daily gain was positively correlated with it.

During suckling period, the milk yield of the mother is a decisive factor in the development of lambs. Snowder and Glimp (1991) found a significant positive 
correlation between the mother's milk yield and weight gains of lambs, lasting until eight weeks of life. In view of the incompletely developed function of the rumen, another important factor is the quality of the protein supplied in the diet. According to Urbaniak and Potkański (1991a), partial substitution of SBM by RSM did not affect the growth of suckling Merino lambs, but when the substitution was total (Potkański et al., 1991), lamb performance was significantly poorer (by about $22 \%$ ).

The decrease in the growth rate of lambs in groups $\mathrm{M}$ and $\mathrm{L}$ in comparison with group $\mathrm{H}$ (Table 4) as the result of decreasing the protcin content of the diet, was greater in group $\mathbf{M}$ (males by 23 , females by $7 \%$ ) than when the protein level was even further decreased in group $\mathrm{L}$ (males by 16 , females by $6 \%$ ). The explanation for the greater decrease in the growth rate in group $\mathrm{M}$ may lie in the difference in the milk yields of the mothers in these groups (Snowder and Glimp, 1991), but this parameter was not determined in our experiment. Rams reacted with a greater decline in weight gains than ewes in response to the decreased protein supply in the concentrate. In relation to group $\mathrm{H}$, this decline in groups $M$ and $L$ was three times that of ewes. Because the animals were kept in a flock, it is not known whether this is the result of differences in feed intake. Ulbrich et al. (1990) showed that when ewes and rams were kept separately, feed intake of German Merino lambs per $\mathbf{k g}^{0.75}$ was equal, but the gains of the rams were significantly higher and they utilized protein and energy for growth better. Other authors, e.g. Gut et al.(1989) and Taibi et al. (1992) found that ewes have a $15-18 \%$ slower growth rate than rams.

The weight gains of suckling lambs (Table 4) were relatively low, and lower than the values given by various authors for lambs of various breeds (Kosanovic et al., 1977; Potkański et al., 1991; Urbaniak and Potkański, 1991). The rams and ewes in group $M$ grew at the same rate between 28 days of age and weaning, while in groups $\mathrm{H}$ and $\mathrm{L}$ the ewes showed 17 and $7 \%$ lower daily gains. This may be related to the dependence between birth weight of rams and their growth rate during the suckling period described by Villette and Theriez (1981). The ewcs in group $\mathrm{H}$ weighed about $9 \%$ less than rams at two days of age, in the remaining groups this difference was about $4 \%$.

Utilization of feed DM by suckling lambs was similar in all groups, while the reduction of the protein level improved its utilization by 8 and $20 \%$ in groups $\mathrm{M}$ and $\mathrm{L}$, respectively (Table 5). The daily ME maintenance requirement of suckling lambs was calculated using the coefficient $418 \mathrm{~kJ} / \mathrm{kg}^{0.75}$, according to Theriez et al. (1982). A somewhat smaller value of this coefficient, $370 \mathrm{~kJ} / \mathrm{kg}^{0.75}$ is given for castrated rams by Alam et al. (1991), while Hussein and Jordan (1990) found that suckling lambs use even up to $60-66 \%$ of the gross energy contained in consumed milk for the production of heat and only $34-40 \%$ of it is retained in their bodies. This high heat production in suckling lambs is thus an important 
factor determining maintenance requirements, which are greater in suck ling than in weaned lambs.

The consumption of $\mathrm{DM} / \mathrm{kg}$ metabolic weight in groups receiving less protein in the concentrate than recommended by Polish standards (1993) was $15 \%$ lower (regardless of its level) than when the lambs were fed the mixture with the highest protein content. Purroy et al. (1993) report that rams receiving $12 \% \mathrm{CP}$ in their ration consumed significantly less feed per $\mathrm{kg}^{0.75}$ than those fed a diet containing 15 or $18 \%$ protein. Feed intake per kg metabolic weight by suckling lambs is not related to their birth weight (Villette and Theriez, 1981).

In comparison with the requirements given in the Nutrient Requirements for Cattle and Sheep, Traditional System (1993), the DM intake was 10,24 and 22\% lower in groups $\mathrm{H}, \mathrm{M}$ and $\mathrm{L}$, respectively, which indicates that fattened lambs (Pająk et al., 1993), similarly as suckling lambs do not consume the expected amount of DM in their diets. This results in an approximately $14 \%$ lower CP intake in group $\mathrm{H}$ in relation to standards.

\section{Fattening period}

The decrease in the proportion of protein not degraded in the rumen in groups $\mathrm{S}^{\mathrm{L}}$ and $\mathrm{R}^{\mathrm{L}}$ in comparison with groups $\mathrm{S}^{\mathrm{H}}$ and $\mathrm{R}^{\mathrm{H}}$ was the same (Table 7), but as earlier studies have shown (Żebrowska et al.,1991), the digestibility of nitrogen in the small intestine in diets containing SBM is slightly higher than in diets containing RSM.

A comparison of intakes of protein digestible in the intestine with values recommended by INRA standards (1993) suggest that the synthesis of bacterial protein in the rumen in groups $\mathrm{S}^{\mathrm{H}}$ and $\mathrm{R}^{\mathrm{H}}$ was limited by the amount of available energy, while in the remaining groups synthesis was limited by the availability of nitrogen (Table 8). In groups $\mathrm{S}^{\mathrm{L}}$ and $\mathrm{R}^{\mathrm{L}}$ the amount of PDIN intake was 10 and $7 \%$ less than the amount of PDIE consumed in groups $\mathrm{S}^{\mathrm{H}}$ and $\mathrm{R}^{\mathrm{H}}$, respectively.

When fattened lambs were fed according to Polish standards (1993), DM intake was less by 12 and $17 \%$ in the SBM and RSM groups, respectively. In the groups receiving a smaller amount of protein in their ration, DM intake did not depend on the source of protein and was smaller by about $16 \%$ than given in the standards. Earlier studies (Pająk et al., 1993) also showed that during fattening, Polish Lowland lambs did nol consume the amounts of DM given in the nutritional requirements. Sinclair et al. (1991) did not, however, find significant differences in feed intake by 14-week-old Suffolk x Blackface ram lambs when fed isocaloric rations based on barley and containing 12 or $18 \%$ CP in DM. McCarthy et al. (1987) also report that intake of ration DM by cross-bred lambs did not depend on the protein level in the ration when 12 or $14 \%$ was provided. 
Possibly, an explanation for the insufficient intake of DM by Polish Lowland lambs in relation to values given in the requirements can be the insufficient level of fibre in the diet (under 11\%). Perez-Lanzac et al. (1988) found that during fattening of cross-bred lambs, DM consumption rose when the fibre content increased from 10 to 15 or $20 \%$, but was provided in a granulated form with various proportions of lucerne meal instead of cereals.

A comparison of the intake of protcin digestible in the intestine with INRA standards (1993) shows that the PDI requirement was exceeded only in group $\mathrm{S}^{\mathrm{H}}$ by about $7 \%$, while in group $\mathrm{R}^{\mathrm{H}}$ there was a $4 \%$ deficiency of PDIE, while in the remaining groups there was a $9-10 \%$ deficiency of PDIN. The deficiency in the amount of protein digestible in the intestine did not affect the weight gains of the lambs.

The results of this and earlier experiments (Pajak et al., 1993) indicate that Polish Lowland lambs fattened to $38-40 \mathrm{~kg}$ liveweight have an average daily gain of about 220-240 $\mathrm{g}$ both when the animals are fed diets containing about $14-15 \%$ as well as $16-18 \% \mathrm{CP}$ in the DM of the ration (Table 9). Other authors (Shindarska, 1987; Sinclair et al., 1991 and Urbaniak, 1986) also failed to find differences in weight gains of lambs fed rations containing $12-19 \%$ protein. However, McCarthy et al. (1987) report that the daily gains of cross-bred lambs were higher when they were given a concentrate containing $14 \% \mathrm{CP}$ than when this level was $12 \%$. Purroy et al. (1993) also found a highly significant slower growth rate of rams receiving $12 \% \mathrm{CP}$ in their rations as compared with those given 15 or $18 \%$. Polish Merino lambs gained about $180 \mathrm{~g}$ daily, regardless of the protein level in the ration, if its content was not lower than $14 \%$ of DM (Jayaprakasch, 1984; Żebrowska et al., 1992). Gut et al. (1989) report that during the period of 100-150 days of age, the average daily weight gain of the Polish Merino was $200 \mathrm{~g}$. In the fattening of Merino and cross-bred rams, Korman (1994) obtained somewhat better results; lambs receiving 15\% CP in DM gained $220 \mathrm{~g}$ daily, using $720 \mathrm{~g}$ protein $/ \mathrm{kg}$ weight gain, while when a ration containing $14 \%$ protein, the rams gained $235 \mathrm{~g}$ daily, using $610 \mathrm{~g} / \mathrm{kg}$ gain.

Total substitution of SBM with rapeseed oilmeal of a double low Polish variety had an unfavourable effect on the gains of suckling lambs (Potkański et al., 1991), while having no effect on either gains or feed utilization by fattened lambs, which confirms the results of Żebrowska et al. (1991) and Urbaniak and Potkański (1991b). Pakulski and Osikowski (1994) also found that total substitution of SBM with RSM did not have a negative effect on fattening and feed utilization by Merino lambs fattened to $40 \mathrm{~kg}$ liveweight.

Intake of $C P$ was almost $1 / 4$ lower in groups $\mathrm{S}^{\mathrm{L}}$ and $\mathrm{R}^{\mathrm{L}}$ than given in the requirements (Table 8); this difference is sufficient to affect its utilization.

Utilization of DM in this study (Table 9) was somewhat worse than in earlier studies (Pająk et al., 1993) carried out on Polish Lowland lambs, and similarly 
did not depend on the level of protein in the diet, which is confirmed by the data of Sinclair et al. (1991) and McCarthy et al. (1987).

Rams from groups $\mathrm{M}$ and $\mathrm{L}$, that grew more slowly during suckling period (134 and 146 vs $173 \mathrm{~g}$ - Table 4) exhibited somewhat greater body weight gains during fattening and utilized feed DM more effectively $(P \leqslant 0.05)$ than the lambs in group $\mathrm{H}$ (Table 11). The reasons for this are difficult to explain and require further study. Growth compensation is probably one of the mechanisms involved here (Ledin, 1983; Turgeon et al., 1986), although in the works of Drouillard et al. (1991) on cross-bred lambs and by Caldiera et al. (1993) on Precoce Merino lambs between 20 and $40 \mathrm{~kg}$ liveweight, growth compensation was not observed.

\section{CONCLUSIONS}

The protein level of the ration did not have a significant effect on the weight gains and body weight of suckling lambs, yet when its level was decreased the lambs consumed less feed, which caused a slight fall in daily gains.

During suckling period, rams respond to limiting the protein content of the diet by a larger decline in weight gains than ewes.

Replacement of soyabean oilmeal with rapeseed oilmeal of a double low variety did not cause a significant decrease in fattening performance of lambs.

Lambs fed the rations containing the highest protein content $(16.7 \%)$ during suckling period grew slightly slower during fattening and showed worse feed utilization than the remaining lambs.

\section{REFERENCES}

Alam M.R.. Poppi D.P.. Sykes A.R., 1991. Comparative energy and protcin utilization in kids and lambs. J. Agric. Sci., Camb. 117, 121-127

Caldeira R.M., Santos-Silva J.M.B., Vaz-Portugal A., 1993. Effects of two types of feed restriction and subsequent releeding on the development and carcass composition of lambs (in Portuguese). Rev. Portug. Cien. Vet. 88, 507, 118-127

Drouillard J.S., Klopfenstein T.J., Britton R.A., Bauer M.L., Gramlich S.M., Wester T.J., Ferrell C.L.. 1991. Growth. body composition, and visceral organ mass and metabolism in lambs during and after metabolizable protein or net energy restrictions. J. Anim. Sci. 69, 3357-3375

Ensminger M.E., Oldfield J.E., Heinemann W.W., 1990. Feeds and Nutrition. $2^{\text {nd }}$ Edition. Ensminger Publishing Co., Clovis, California, s.1544

Gut A., Śliwa Z., Ślósarz P., 1989. Growth of lambs from a meat line in relation to amount of Suffolk inheritance (in Polish). Pr. Komis. Nauk Rol. Leś. 67, 59-64 
Hussein H.S., Jordan R.M., 1990. Energy utilization by lactating ewes and suckling lambs: a review. Sheep Res. J. 6, 30-39

INRA: Ruminant Nutrition. Recommended Allowances and Feed Tables, 1993. Jarrigc R.Ed.. Polish Edition. Jablonna

Jayaprakash, 1984. Influence of various sources of nitrogen in the diet on the digestibility, nitrogen metabolism, growth and carcass composition of Polish Merino lambs. Ph.D. Thesis, The Kielanowski Institute of Animal Physiology and Nutrition, Jabłonna

Korman K., 1994. The influence of the system of feeding standards on the effects of fattening lambs (in Polish). Prz. hod., Zesz. nauk. 13, 261-270. Chow i hodowla owiec. PTZ, Warszawa

Kosanovič M., Jvos R., Krajinovič M., 1977. Intensive production of lamb meat in the suckling period (in Serbo-Croatian). Zb. Radova, Institut za Stocarstvo, Novi Sad. 9/10, 109-115

Ledin I., 1983. Effect of restricted feeding and realimentation on compensatory growth, carcass composition and organ growth in lambs. Swedish J. Agric. Res. 13, 3, 175.187

MAFF, 1975. Energy Allowances and Feeding System for Ruminants. London, Techn. Bull. 33

McCarthy F.D., Wahlberg M.L., McClure W.H., 1987. Supplementation of growing lambs with niacin: response to differing protein levels and source. Appl. Agric. Res., 2, 3, 170-174

Mehrez A.Z., Ørskov E.R., 1977. A study of the artificial fibre bag technique for determining the digestibility of feeds in the rumen. J. Agric. Sci., Camb. 88, 645-650

Nutrient Requirements of Cattle and Shecp. Traditional System (in Polish). 1993. Instytut Zootechniki, Kraków

Ørskov E.R., McDonald 1., 1979. The estimation of protein degradability in the rumen from incubation measurements weighted according to rate of passage. J. Agric. Sci., Camb. 92, 499-503

Pająk J.J., Słowak M., Dakowski P., 1993. Fattening performance of Polish Lowland lambs related to protein level in the diet. J. Anim. Feed Sci. 1, 193-203

Pakulski T., Osikowski M., 1994. The use of "OO" rape (seeds and meal) and the INRA - 1988 fecding standards in fattening lambs (in Polish). Prz. hod., Zesz. nauk. 13, 279-285. Chów i hodowla owiec. PTZ, Warszawa

Perez-Lanzac J., Bendicho-de-Combeilas J., Castro-Pereira A., 1988. Technology of forage for lambs. 1. Growth and composition of the digestive tract with pelleted feeds with different amounts of fibre (in Spanish). Avances Alim. Mejora Animal. 28, 3-10

Potkański A., Urbaniak M., Michalak W., 1990. Medium intensive lamb fattening with high silage rations (in Polish). Rocz. AR Poznań, Zoot. 39, 59-69

Potkański A., Urbaniak M., Kujawa A., 1991. Rapeseed oilmeal as a protein source in CJ feed mixture for fecding suckling lambs (in Polish). Rocz. AR Poznań, Zoot. 41, 45-53

Purroy A., Echaide H., Munoz. F., Arana A., Mendizabal J.A., 1993. The effect of protein level and source of legume seeds on the growth and fattening of lambs. Livest. Prod. Sci. 34, 93-100

Shindarska Z., 1987. Effect of the energy to protein ratio of diets on deposition of fat and protein in the carcass of fattened lambs. 2. Experiments with diets equal in energy with different amounts of protein (in Bulgarian). Zhivot. Nauki 24, 11, 39-44

Sinclair L.A., Gaibraith H., Scaife J.R., 1991. Effect of dietary protein concentration and cimaterol on growth and body composition of entire male lambs. Anim. Feed Sci. Technol. 34, 181-192

Snowder G.D., Glimp H.A., 1991. Influcnce of brecd, number of suckling lambs, and stage of lactation on ewe milk production and lamb growth under range conditions. J. Anim. Sci. 69. $923-930$

Taibi L., Pilla A.M., Dell'Aquila S., Catillo G., Scardella P., 1992. Meat production of crossbred milk sheep. 2. Growth of lambs from weaning to slaughter and sla ughter data (in Italian). Zoot. Nutr. Anim. 18, 6, 285-294 
Theriez M., Villette Y., Castrillo C., 1982. Influence of metabolizable energy content of the diet and of feeding level on lamb performance. II. Utilization of metabolizable energy for growth and fattening. Livest. Prod. Sci. 9, 487-500

Turgeon O.A. Jr., Brink D.R., Barlle S.J., Klopfenstein T.J., Ferrell C.L., 1986. Effects of growth rate and compensatory growth on body composition in lambs. J. Anim.Sci. 63, 770-780

Ulbrich M., Al-BakkourJ., Fix H.P.. 1990. Separate fattening of male and female lambs (in German). Tierernähr. Futterung. 16, 17-22

Urbaniak M., 1986. Protein requirement of Merino lambs fattened from 20 to $40 \mathrm{~kg}$ live weight (in Polish). Rocz. AR Poznani, Rozpr. nauk. No. 161

Urbaniak M.. Potkański A., 199la. Effect of rapeseed oilmeal content in CJ concentrate mixture on weight gains of lambs and calves and on thyroxine and triiodothyronine levels in blood serum (in Polish). Rocz. AR Poznań, Zoot. 41, 37-44

Urbaniak M., Potkański A.. 1991b. Effect of soyabean and rapeseed oilmeals and ground pea seeds on shcep fertility (in Polish). Rocz. AR Poznań. Zoot. 41, 55-61

Villette Y.. Theriez M., 1981. Effect of birthweight on lamb performance. 1. Level of feed intake and growth (in French). Ann. Zootech. 30. 2, 151-168

Żebrowska H., Żebrowska T.. Długołęcka Z., Pająk J., 1991. Comparison of protein digestion in different sections of digestive system of sheep fed on diets containing rapesced meal or soyabean meal (in Polish). Rocz. Nauk. Zoot., Monogr. Rozpr. 29, 125-133

Żebrowska T., Żebrowska H., Pająk J., 1992. Protein content in the diet for fattening lambs. 1. Liveweight gain, efficiency of feed utilization and digestibility of nitrogen and amino acids in the small intestine. J. Anim. Feed Sci. 1, 15-25

\section{STRESZCZENIE}

Trzy grupy po 48 jagniąt ssących polskiej owcy nizinnej dokarmiano do woli od 11 dnia życia sianem ląkowym i mieszanką treściwą zawierającą: 16,$7 ; 14,7$ lub $12,3 \%$ biakka ogólnego (BO) w suchej masie (SM). Z obniżeniem zawartości białka w mieszance zmniejszało się jej spożycie, wzrastal natomiast udział SM siana w calkowitym pobraniu SM z 41 do ok. 43 i $46 \%$, odpowiednio. Nie stwierdzono statystycznie istotnych różnic w przyrostach (tryczki-173, 134 i 146 oraz jarki-144, 134 i 136 g dziennie) i masie ciała jagniąt ssących w okresie od 28 dnia życia do odłączenia. Zużycic SM i energii metabolicznej (ME) na kg przyrostu bylo podobne $(2.16 ; 2.17$ i $2.08 \mathrm{~kg} \mathrm{SM}$ oraz ok. 25 MJ ME), natomiast wykorzystanie białka poprawiało się przy zmniejszeniu jego poziomu w dawce (322, 297 i $258 \mathrm{~g} \mathrm{BO} / \mathrm{kg}$ przyrostu, odpowiednio).

W okresie tuczu nie stwicrdzono istotnych różnic w przyrostach 92 tryczków (od 221 do $232 \mathrm{~g}$ dziennie) żywionych w czterech grupach (po 23) dawkami różniącymi się poziomem (16 vs $14 \%$ BO w SM) i źródłem białka (poekstrakcyjna śruta sojowa - SBM lub z rzepaku krajowej odmiany podwójnie ulepszonej - RSM). Wykorzystanie SM paszy było nieco lepsze w grupie $S^{H}$ otrzymującej SBM niż RSM (grupa $\mathrm{R}^{\mathrm{H}}$ ) w dawce wysokobiałkowej (4.43 vs $4.67 \mathrm{~kg} \mathrm{SM} / \mathrm{kg}$ przyrostu, odpowiednio), zaś przy obniżeniu poziomu białka nie różniło się (4.54 vs 4.51 ). Wykorzystanie BO w obrę̧bie grup o jednak owym poziomie białka nie różnilo się statystycznie, było natomiast $(P \leqslant 0.05)$ gorsze w grupie $\mathrm{R}^{\mathrm{H}}$ (74l vs 639 i $634 \mathrm{~g} / \mathrm{kg}$ ) niż w obydwóch grupach ( $\mathrm{S}^{\mathrm{L}}$ i $\mathrm{R}^{\mathrm{L}}$ ) żywionych dawkami o mnicjszej jego zawartości.

Jagnięta żywione w okresie odchowu mieszanką o największej zawartości białka ( $16.7 \% \mathrm{w} \mathrm{SM})$ w okresie tuczu rosły nieco wolniej ( 217 vs 232 lub $227 \mathrm{~g}$ dziennie) i zużywały istotnie $(P \leqslant 0,05)$ więcej paszy (4.83" vs $4.30^{\mathrm{b}}$ lub $4.49^{\mathrm{b}} \mathrm{SM} / \mathrm{kg}$ przyrostu) niż żywione mieszanką o zawartości 14,7 lub $12,3 \%$ BO w SM. 